\title{
Factors Influencing Corruption Actions with Parliamentary Behavior as Moderating Variables (Polewali Mandar Regency DPRD Study)
}

\author{
Jamaluddin M. ${ }^{1}$, Mediaty ${ }^{2}$, Harryanto ${ }^{3}$, Abdul Hamid Habbe ${ }^{4}$ and Lili Aprilianti ${ }^{5}$ \\ ${ }^{1}$ Universitas Islam Negeri Alauddin \\ ${ }^{2}$ Universitas Hasanuddin \\ ${ }^{3}$ Universitas Hasanuddin \\ ${ }^{4}$ Universitas Hasanuddin \\ ${ }^{5}$ Universitas Islam Negeri Alauddin
}

\begin{abstract}
This study aims to examine the greedy effect of greed, opportunity, need and disclosure on the behavior of APBD corruption with parliamentary behavior as a moderating variable. This research is a quantitative research using a descriptive approach. The method of data collection is by handing out questionnaires. That Data analysis is done by applying multiple linear regression analysis and regression moderating analysis with residual test approach. The results of the study with multiple linear regression analysis indicate that greedy, opportunity, and disclosure have a positive impact on the behavior of APBD corruption, while need does not affect the behavior of APBD corruption actions. The analysis of the moderating variable with the residual approach shows that parliamentary behavior can moderate greed, opportunity, need and disclosure on the behavior of APBD corruption. This means that the greater the greed, the greater the opportunity and disclosure, the higher the behavior of the APBD corruption, but if the individual has good parliamentary behavior, it will reduce the behavior of the APBD corruption.
\end{abstract}

Keywords: Greed, Opportunity, Need, Disclosure, parliaments Behavior and Corruption

\section{Introduction}

Fraud is interpreted as a deviant or illegal act carried out by individuals or groups intentionally to take personal advantage and harm others. According to The Association of Certified Fraud Examiners classifies three types of fraud or referred to as fraud trees, asset misappropriation, fraudulent statements and corruption. Asset misappropriation or misuse of assets is the fraud that involves thievery of assets belonging to an entity (Elder et al, 2008). The Fraudulent statements and corruption ae types of fraud which abuse or misuse of state and corporate money for personal or another people's benefit (Marliani and Jogi, 2015).

The type of fraud that is handily detected or found out is corruption because is carried out not only by one person but carried out in groups. Corruption occurs in many countries that have a weak law enforcement system, as well as a lack of awareness of good governance so that the integrity factor is still questionable (Widarti, 2015). Corruption also occurs in many developing countries, one of which is our beloved country, Indonesia, which has become a phenomenal issue because there have been many cases that unfold on the surface regarding these deviant actions.

In early 2017, Transparency International released the results of efforts to eradicate corruption carried out in 176 countries. The perception index of corruption places Indonesia in the 90th place with a score of 37. Although Indonesia's score has increased by one point, it was lower than the previous year, which is a two-level decline. The Danish and New Zealand countries ranked top with a score of 90 which was marked by transparency in the bureaucratic process, meaning that these countries allowed citizens to access information about how the public budget was used. Whereas in the Continent of Asia, Singapore is the country with the highest ranking of the freest corruption, which is ranked seven with a score of 87 . Then followed by Brunei Darussalam in the rank 41 and Malaysia ranked 55. 
The declining rating obtained by Indonesia is one of the concrete evidences that confirms that the of corruption in Indonesia is getting acute. corruption have become a culture in Indonesia and have even been ingrained. Corruption in Indonesia has spread on almost all sides and levels of life. In besides to reaching the lowest level, corruption also infects bureaucracy such as people's representative institutions, military institutions, the businesses world, banking, education, religious institutions, and even institutions related to corruption eradication such as the police, judiciary and prosecutors (Muzadi, 2006).

The government is essentially for community service, it is not held to serve itself, but serves the community and creates conditions so that every member of the community develops their abilities and creativity (Rasyid, 1998). But, in Indonesia, the public sector is experiencing a shock due to many deviations. Budget Planning and Regional Expenditure or APBD is one area that is prone to corruption. The prone point of corruption in the APBD budgeting process is at the planning, implementation, and accountability and evaluation stages.

The budget is an instrument of planning and management control that plays an important role in public sector organizations to be recognized, given advice, criticized, and argued (Mahmudi, 2011). The Regional Revenue and Expenditure Budget (APBD) is the annual financial plan of regional governments in Indonesia starting from January 1 to December 31, which has been approved by the Regional People's Representative Council or DPRD.

In reforming regional autonomy there were several changes in executive relations with the legislature. One of the changes was that the executive and legislative boards have full authority in compiling the Regional Revenue and Expenditure Budget that was never been done. Another implication of regional autonomy was the transfer of funds coupled with the implementation of budgeting reforms and reforming the regional financial accounting system (Halim, 2003). Accountability, participation and transparency which are the elements of Good Government Governance were new paradigms that must be realized in the budgeting process. Based on the Minister of Interior Decree No. 13/2006 concerning budgeting procedures that undergo various changes including relying on public interests, managed with good results and low costs, managed with a performance-oriented approach, principles of transparency and accountability, fostering professionalism of work, and paying attention to the principle of value for money ( Maulana, 2016).

The euphoria of the development of regional autonomy has had a good impact accompanied by adverse impacts. According to Khudori (2004) the impact that is of concern was the emergence of deviant actions called corruption. There were many corruption cases involving DPRD members. The case that made the image of legislators increasingly tarnished was the E-KTP corruption case that ensnared the chairman of the RI DPD, Setya Novanto. In the corruption case of the electronic KTP or E-KTP procurement project, Novanto as w name as suspect for the second time by the Corruption Eradication Commission (KPK). The determination of the suspect was first dropped because Novanto won a pretrial law suit.

In addition, in West Sulawesi Province there was also an alleged corruption case of the Regional Budget which estimatedly caused a loss of Rp. 80 billion in the country and the case was still rolling in the court. Until now 4 suspects have been determined, they are the chairman, deputy chairman of the West Sulawesi Provincial DPRD. However, the determination of the 4 suspects did not stop KEJATI SulSelBar to conduct, further examination of the other DPRD members.

Based on the theory of Triangle, someone who commits fraud is influenced by three factors, pressure, opportunity or opportunity and the last is rationalization or justification. Whereas in GONE's theory there are four factors of fraudulent actions, namely Greed, Opportunity, Need and Disclosure. Greed is related to the existence of greedy behavior that potentially exists in everyone; opportunity is related to the condition of the organization, agency or society in such a way, so that there is an opportunity for someone to commit fraud; Need or need is related to the factors needed by individuals to support a reasonable life; Disclosure is related to actions or consequences confronted by fraud perpetrators if the perpetrators are found to be cheating (Bologna in Lisa, 2013). 
Behavior is a set of behaviors possessed by humans and influenced by customs, attitudes, emotions, values, ethics, power, persuasion and / or genetics (Doroles, 2005). One that affects individual behavior is power, so individuals who have power have different behaviors than individuals who do not have power. Likewise, DPRD members or parliamentarians they have different behaviors than other individuals because they are influenced by their power. The behavior of the parliament can influence the causes of the acts of corruption in the APBD involving regional officials, DPRD members. The objectives of this study include: 1) To find out the greed effect on APBD corruption behavior, 2) To determine the opportunity effect on APBD corruption behavior, 3) To determine the effect of need on APBD corruption behavior, 4) To determine the effect of disclosure on action behavior APBD corruption, 5) To determine the effect of moderating parliamentary behavior on greedy relationships with APBD corruption behavior, 6) To determine the effect of moderating parliamentary behavior on opportunity relations on APBD corruption behavior, 7) To determine the effect of moderating parliamentary behavior on relationship needs to behavior APBD corruption acts, 8) To determine the effect of moderating parliamentary behavior on the relationship of disclosure to the behavior of APBD corruption acts.

The theory of GONE was first put forward by Jack Bologne in 2006. In the GONE theory it is said that there are factors that cause cheating including Greedy or greed, related to the existence of greedy behavior that potentially exists within everyone; Opportunity, related to the state of the organization or agency or community in such a way that there is an opportunity for someone to commit fraud; Need or need, related to the factors needed by individuals to support a reasonable life; Disclosures related to actions or consequences confronted by fraud perpetrators if the perpetrators are found to be cheating (Bologna in Lisa, 2013).

Greed and need factors relate to individuals from the perpetrators of fraud or fraud, namely individuals or groups both in internal and external organizations that commit fraud that harm others. Whereas opportunity factors and disclosures relate to the victims of fraud occurring, which are organizations, agencies, communities whose interests are harmed.

APBD Regional Corruption Actions. The Association of Certified Fraud Examiners (ACFE), divides fraud or fraud in 3 types based on actions that are deviations from assets or Asset Misappropriation, false statements or false statements or Fraudulent Statements, and corruption or Corruption. Corruption is a type of fraud that is detected because it involves cooperation with other parties such as bribery and corruption, where this is the most common type in developing countries where law enforcement is weak and there is still a lack of awareness of good governance so that His integrity is still questionable. This type of fraud often cannot be detected because the parties working together enjoy benefits or mutual symbiosis.

Greed. Greed is related to the existence of greedy behavior that potentially exists within every human being (Bologna in Lisa, 2013). Greed is one of the factors driving someone to cheat. Someone will commit fraud because basically humans have a greedy nature, never feel satisfied about what they already have and are not satisfied with what they have. The greedy nature of the individual is caused by the lack of gratitude for the blessings of Allah Almighty. that has been given to him.

Corruption is also called corruption by greedy or corruption due to greed because the perpetrators in general are materially enough (Kuntadi, 2015). Individual al commit corruption because of the lack of satisfaction with what they have. When individuals already have a pile of money, they are eager to have mountain money. The desire to increase wealth is certainly commonplace for every individual, but when the road taken is wrong, it is certainly not true, moreover the action is carried out by state and regional officials who have gained trust from the community. State or regional officials in carrying out their duties and responsibilities must be carried out solely for the interests of the people not to enrich themselves or their groups.

Opportunity. Opportunity is a situation that opens opportunities to allow fraud to occur. According to Gagola in Ratmono et al (2014), opportunities arise when the control system is weak, and individuals commit fraud if there is an opportunity. Opportunity is considered as a trigger factor for 
someone to commit fraud because if a fraudster does not have the opportunity to do so, fraud will not occur, this is supported by various theories, such as the Triangle theory proposed by Creessey in the 1940s, Diamond theory proposed by David T. Wolfe and Dana R. Hermanson in 2004, and Pantagon theory proposed by Crowe Howarth in 2011. According to Albrecht (2012) in Apriani et al (2017) opportunity is a situation that allows someone to commit fraud, a situation that is considered safe by the perpetrator for cheat with the assumption that cheating will not be detected.

Need. Need or need is related to the factors needed by individuals to support a reasonable life (Bologna in Lisa, 2013). Need is an internal factor inherent in a person doing deviant actions. Kurniawan (2013), states that everyone has more needs so that it can be a driver of fraud. To meet these needs people will do anything even if they must commit fraud.

Disclosure. According to Bologna in Lisa (2013), disclosure is a factor that relates to organizations as victims of fraud. Disclosure is related to actions or consequences faced by perpetrators of fraud if the perpetrator is found to be committing fraud. Disclosure of fraud has not guaranteed the recurrence of the fraud by both the same perpetrator and other actors. Therefore, each perpetrator of fraud should be subject to severe sanctions if his actions are revealed.

Disclosures that may be the cause of corruption are also supported by theories other than green theory in this study. One related theory is the prevention theory proposed by Anselm Von Feurbach regarding the psychologische zwang. Anselm said that if everyone understood and knew that violating the rule of law was threatened with criminality, the person understood and knew that he would also be sentenced for the crime he committed so that everyone was prevented from intentionally evil so that in the soul each person had pressure on criminal threats (Marlina, 2011)

Parliament behavior. Behavior is a set of behaviors possessed by humans and influenced by customs, attitudes, emotions, values, ethics, power, persuasion and / or genetics (Doroles, 2005). One that affects individual behavior is power, so individuals who have power have different behaviors than individuals who do not have power. Likewise, the DPRD members or parliamentarians they have different behaviors than other individuals because they are influenced by their power.

The Regional People's Legislative Assembly (DPRD) is a representative body of the people that functions as a regional government organizer both in the provinces, districts and cities. DPRD members are elected by the people through a general election that lasts for five years. In the organizational structure the leadership of the DPRD consists of a chairman and a maximum of 3 deputy chairmen. To maximize the performance of DPRD members who are the bridge connecting people's aspirations with the government and for the achievement of the success of local governments, a code of ethics is formed which aims as a benchmark for attitudes and behavior. The behavior of DPRD members is regulated in Government Regulation No. 16 of 2010 concerning guidelines for drafting the Regional People's Legislative Assembly regulations which contain several provisions.

\section{Research Methodology}

This type of research is a quantitative research using descriptive approach. The purpose of this descriptive study is to test hypotheses or answer questions related to the status of the subject under study. This type of research is generally related to the assessment of attitudes or opinions on individuals, groups or organizations, events or procedures.

The type of data used in this study is the type of subject data. Subject data is a type of research data in the form of opinions, attitudes, and characteristics of a person or group of people who are the subject of research (respondents). The data sources used in this study are primary data and secondary data. Primary data is data directly from research data sources obtained directly from the original source and not through intermediary media (Rahmawati and Usman, 2014). Primary data in this study are responses that will be answered directly by the research subject through questionnaire. While secondary data is data that is obtained indirectly because it is obtained through intermediary media. Secondary data can also be interpreted as data that has been previously collected by other parties and 
then published. Intermediary media used to obtain secondary data is through previous journals, books, and researches.

Data analysis is used to simplify data so that it is more easily interpreted, processed using existing formulas or rules according to the research approach. Data analysis is an activity carried out to process and analyze collected data. In this study, researchers used quantitative analysis. Quantitative analysis is a form of analysis that is intended for large data grouped into categories in the form of numbers. Data analysis method uses descriptive statistics, data quality test, classic assumption test and hypothesis testing through the SPSS program

\section{Result and Discussion}

Greed Influence on the Behavior of the Regional Budget Corruption. The first hypothesis (H1) proposed in this study is that Greedy influences the behavior of APBD corruption acts. The results of the analysis show that the unstandardized beta coefficient is 0.311 and the significance level is 0.024 which is smaller than 0.05 Based on the results of the analysis shows that Greedy has a positive effect on the behavior of APBD corruption acts. This means that Greedy or greedy attitude that is potentially owned by individuals is the cause of the APBD corruption behavior, thus the first hypothesis is accepted.

The results of this study indicate that greedy has an influence on fraud, the behavior of corruption in the APBD. Greedy or greed is an internal factor that causes potential fraud to be experienced by everyone. The greedy nature in a person is caused by the absence of gratitude in oneself for the pleasure that has been given by Allah SWT. A person who commits corruption is not satisfied with his condition. When you have a stack of money, you want to have a mountain of money. The results of this study are also in line with Gone's Theory put forward by Jack Bologne in 2006 which explained that there were four factors in the occurrence of fraud or fraud where one of these factors was greedy. Greed in the theory is an internal factor, where greed will require fulfillment beyond what is needed

The results of this study are in line with research conducted by Indrawati et al. (2017) which aims to determine the causes of academic fraud in accounting students in Bali, Ismatullah and Eriswanto (2016) which aims to determine the causes of academic fraud at Muhammadiyah Sukabumi University, Zaini (2016) which aims to determine the causes of academic fraud in Madura Accounting Students. The results in these studies prove that greedy has a positive effect on cheating behavior.

The Influence of Opportunity Against the Behavior of the Regional Budget Corruption. The second hypothesis (H2) proposed in this study is that Opportunity influences the behavior of APBD corruption. The results of the analysis show that the unstandardized beta coefficient is 0.243 and the significance level is 0.042 which is smaller than 0.05 . Based on the results of the analysis show that Opportunity has a positive effect on the behavior of APBD corruption actions. This means that Opportunity is the cause of fraud, which is the behavior of APBD corruption. The greater the opportunity that is obtained by individuals or groups, the greater the behavior of corruption in the APBD. Thus, the second hypothesis is accepted.

The results of this study indicate that Opportunity has an influence on fraud, the behavior of corruption in the Regional Budget. Opportunity is an opportunity for individuals or groups to commit fraud and the opportunity depends on the circumstances of the organization. So that the cause of the acts of corruption in the APBD is caused by the opportunity to commit fraud. The results of this study are also in line with Gone's Theory put forward by Jack Bologne in 2006 which explains that there are four factors in the occurrence of fraud where one of these factors is opportunity. In this theory, opportunity is an external factor in the occurrence of fraud, the greater the opportunity, the greater the chance for fraud.

The results of this study are in line with research conducted by Indrawati et al (2017) which aims to determine the causes of academic fraud in accounting students in Bali. The results in these studies 
prove that opoortunity has a positive effect on fraudulent behavior.

The Effect of Need on the Behavior of Corruption Actions in the Regional Budget. The third hypothesis (H3) proposed in this study is that the need influences the behavior of APBD corruption. The results of the analysis show that the unstandardized beta coefficient is 0.136 and the significance level is 0.194 which is greater than 0.05 . Based on the results of the analysis show that need does not affect the behavior of the APBD corruption act. Thus, the third hypothesis is rejected.

Based on Gone Theory, which was started by Jack Bologne in 2006, explained that Need or is other internal factors that cause fraud. Need is related to the factors needed by individuals to support a reasonable life (Bologna in Lisa, 2013). An urgent need for needs that are not classified as urgent makes a person commit deviant actions and this is done to support a reasonable life. But based on the results of this study indicate that the need does not have an influence on the behavior of corruption in the APBD.

The absence of need for influence on the behavior of APBD corruption is caused, at the time of research, there was a new government regulation regarding the nominal amount of allowances for members of DPRD throughout Indonesia. The increase in benefits is contained in Government Regulation No. 18 of 2017 concerning Financial and Administrative Rights of the Pimpingan and Members of the Regional People's Representative Council (DPRD). When compared with previous regulations there are several new rules, for example recess benefits. Another new regulation is the provision of welfare benefits for DPRD members in the form of state houses and equipment and transportation allowances. The previous transportation allowance was not obtained by DPRD members now getting position car allowances if they chose not to use official cars or did not get official car facilities. Based on these regulations it can be concluded that the needs of DPRD members have been fulfilled so that they do not have an influence on the behavior of APBD corruption acts. The Effect of Disclosure on the Behavior of Regional Corruption Actions. The fourth hypothesis (H4) proposed in this study is the effect of disclosure on the behavior of APBD corruption actions. The results of the analysis show that the unstandardized beta coefficient is 0.307 and the significance level is 0.025 which is greater than 0.05 . Based on the results of the analysis show that disclosure has a positive effect on the behavior of APBD corruption actions. This means that disclosure is the cause of fraud, which is the behavior of APBD corruption. Thus, the fourth hypothesis is accepted. The results of this study indicate that disclosure influences fraud, namely the behavior of the APBD corruption act. Disclosure is an external factor that causes fraud occurring in relation to actions or consequences faced by fraudulent actors if the perpetrators are found to be cheating. The results of this study are also in line with Gone's Theory put forward by Jack Bologne in 2006 which explains that there are four factors in the occurrence of fraud or fraud where one of these factors is disclosure. Disclosure of fraud has not guaranteed the recurrence of the fraud by both the same perpetrator and other actors. Therefore, each perpetrator of fraud should be subjected to severe sanctions if his actions are revealed.

The results of this study are in line with Research conducted by Indrawati et al (2017) which aims to determine the causes of academic fraud in accounting students in Bali, Zaini (2016) which aims to determine the causes of academic fraud in Madura Accounting Students. The results in these studies prove that disclosure has a positive effect on fraudulent behavior.

The Effect of Parliament Behavior in Greedy Moderating Against the Behavior of the Regional Budget Corruption. Based on the residual test results in table 4.20 shows that the moderating variable X1_M has a count of $-2,494>t$ table 2,0106 with an unstandardized beta coefficient of $-0,339$ and a significance level of 0.016 smaller than 0.05 , parliament Behavior is considered a moderating variable if the value the parameter coefficient is negative and significant. This means that the fifth hypothesis, namely the influence of parliamentary behavior in moderating greedy on the behavior of corruption in the APBD, is acceptable. It can be concluded that the moderating variable parliamentary behavior is included in the type of quasi moderation because the coefficient of $b 2$ is significant and b3 is significant, which means that parliamentary behavior variables include 
independent variables and variables that moderate greedy behavior on APBD corruption. The results of this test mean that the greater the greedy nature of the individual, the higher the behavior of the APBD corruption action, but if the individual has good parliamentary behavior, it will reduce the behavior of the APBD corruption act.

One that affects individual behavior is power, so individuals who have power have different behaviors than individuals who do not have power. Like DPRD members or parliamentarians they have different behaviors than other individuals because they are influenced by their power. The behavior of DPRD members regulated in article 90 of the attitudes and behavior of DPRD members as referred to in Article 89 paragraph (3) letter c number 1 contains several provisions. The DPR, which is a legislative board, experienced a drastic decline of credibility in public due to many cases of corruption revealed on the surface involving members of the DPR and the DPRD.

The Government Regulation on the attitudes and behavior of members of the Regional People's Legislative Assembly is one of the actual steps to create a government that is free from deviant actions and of course members of DPRD throughout Indonesia must comply with these rules. The results of this study indicate that the behavior of DPRD members has an influence on the behavior of APBD corruption acts, where if the DPRD members comply with the applicable rules, they will be able to minimize fraudulent actions, corruption and vice versa. This is in line with the compliance theory proposed by Tyler in 1990. In the theory, it is explained that obedience is a discipline of individuals who obey the rules that have been previously set.

Greedy or greed is the cause of fraud, which is the behavior of corruption in the Regional Budget, but if members of the House of Representatives have parliamentary behavior it will minimize the occurrence of regional budget corruption because indirectly DPRD members can carry out their functions as parliament. There are functions of members of the House of Representatives that are legislative functions, budget functions, and supervisory functions. Therefore, APBD corruption acts that occur due to the greedy nature of the individual and are influenced by the behavior of the parliament which has the authority to prepare the APBD.

Effect of Parliament Behavior in Moderating Opportunity Against the Behavior of the Regional Budget Corruption. The sixth hypothesis (H6) proposed in this study is the influence of parliamentary behavior in moderating the opportunity for the behavior of APBD corruption acts. Based on the residual test results in table 4.20 shows that the moderating variable X2_M has a t count of $-2,271>\mathrm{t}$ table 2.0106 with an unstandardized beta coefficient of -0.312 and a significance level of 0.028 that is smaller than 0.05, parliament Behavior is considered a moderating variable if the value the parameter coefficient is negative and significant. This means that the sixth hypothesis which states that parliamentary behavior moderates the opportunity for the behavior of corruption in the APBD, is acceptable. It can be concluded that the moderating variable, namely parliamentary behavior is included in the type of quasi moderation because the coefficient of b2 is significant and b3 is significant, which means that parliamentary behavior variables include independent variables and variables that moderate opportunities for APBD corruption behavior. The results of this test mean that the greater the opportunity that opens opportunities for fraud, the higher the behavior of corruption in the APBD, but if the individual has good parliamentary behavior, it will reduce the behavior of corruption in the APBD.

Opportunity is an opportunity for individuals or groups to commit fraud and the opportunity depends on the circumstances of the organization and the condition of the community. So that the cause of the acts of corruption in the APBD is caused by the opportunity to commit fraud. Gone's Theory put forward by Jack Bologne in 2006 which explained that there were four factors in the occurrence of fraud or fraud where one of these factors was opportunity.

The Government Regulation on the attitudes and behavior of members of the Regional People's Legislative Assembly is one of the actual steps to create a government that is free from deviant actions and of course members of DPRD throughout Indonesia must comply with these rules. The results of this study indicate that the behavior of DPRD members has an influence on the behavior of APBD 
corruption acts, where if the DPRD members comply with the applicable rules, they will be able to minimize fraudulent actions, namely corruption and vice versa. This is in line with the compliance theory proposed by Tyler in 1990. In the theory, it is explained that obedience is a discipline of individuals who obey the rules that have been previously set.

Behavior of corruption caused by the opening of opportunities so that the appearance of fraud can be minimized by the existence of a behavior parliament. Parliamentary behavior is the behavior of DPRD members who are influenced by their power because they have different attitudes and behaviors than other individuals. The behavior of DPRD members regulated in article 90 of the attitudes and behavior of DPRD members as referred to in Article 89 paragraph (3) letter c number 1 contains several provisions. If DPRD members have attitudes and behaviors that are in accordance with government regulations, it will minimize the occurrence of APBD corruption acts.

The Effect of Parliament Behavior in Moderating Needs for Regional Budget Corruption Actions. The seventh hypothesis (H7) proposed in this study is the influence of parliamentary behavior in moderating need for the behavior of APBD corruption acts. Based on the residual test results in table 4.20 shows that the moderating variable X3_M has a t count of $-2.261>t$ table 2.0106 with an unstandardized beta coefficient of -0.310 and a significance level of 0.028 that is smaller than 0.05 , parliament Behavior is considered a moderating variable if the value the parameter coefficient is negative and significant. It can be concluded that the moderating variable namely parliamentary behavior is included in the type of pure moderation because the coefficient of b2 is not significant and b3 is significant which means that the parliamentary behavior variable is not an independent variable but a variable that moderates the behavior of corruption in the APBD. This shows that the seventh hypothesis which states that parliamentary behavior moderates need for the behavior of APBD corruption acts, is acceptable.

Gone's theory put forward by Jack Bologne in 2006 explained that Need or needs are other internal factors that cause fraud. Need is related to the factors needed by individuals to support a reasonable life (Bologna in Lisa, 2013). An urgent need for needs that are not classified as urgent makes a person commit deviant actions and this is done to support a reasonable life. However, in this study the results were that the need did not have an influence on the behavior of APBD corruption actions because the needs of DPRD members could be fulfilled without having to commit fraud. The needs that have been fulfilled are due to the increase in allowances of members of the DPRD throughout Indonesia as contained in Government Regulation Number 18 of 2017 concerning the Financial and Administrative Rights of the Leaders and Members of the Regional People's Representatives Council. The Government Regulation on the attitudes and behavior of members of the Regional People's Legislative Assembly is one of the actual steps to create a government that is free from deviant actions and of course members of DPRD throughout Indonesia must comply with these rules. The results of this study indicate that the behavior of DPRD members has an influence on the behavior of APBD corruption acts, where if the DPRD members comply with the applicable rules, they will be able to minimize fraudulent actions, namely corruption and vice versa. This is in line with the compliance theory proposed by Tyler in 1990. In the theory, it is explained that obedience is a discipline of individuals who obey the rules that have been previously set.

The Effect of Parliament Behavior in Moderating Disclosure of the Behavior of Regional Corruption Actions. The eighth hypothesis (H8) proposed in this study is the influence of parliamentary behavior in moderating disclosure of the behavior of APBD corruption acts. Based on the residual test results in table 4.20 shows that the moderating variable X4_M has a t count of $-2.882>t$ table 2.0106 with an unstandardized beta coefficient of -0.384 and a significance level of 0.006 smaller than 0.05 , parliament Behavior is considered a moderating variable when the value the parameter coefficient is negative and significant. It can be concluded that the moderating variable, namely parliamentary behavior is included in the type of quasi moderation because the b2 coefficient is significant and b3 is significant, which means that the parliamentary behavior variable includes the independent variable and the variable that moderates disclosure of APBD corruption behavior. This shows that the eighth 
hypothesis which states that parliamentary behavior moderate's disclosure of the behavior of APBD corruption acts, is acceptable.

Disclosure relates to actions or consequences faced by fraudulent actors if the perpetrators are found to be cheating. Disclosure of fraud has not guaranteed the recurrence of the fraud by both the same perpetrator and other actors in a company (Jamaluddin.M 2018). Therefore, each perpetrator of fraud should be subject to severe sanctions if his actions are revealed. The results of this study are also in line with Gone's Theory put forward by Jack Bologne in 2006 which explains that there are four factors in the occurrence of fraud or fraud where one of these factors is disclosure.

The Government Regulation on the attitudes and behavior of members of the Regional People's Legislative Assembly is one of the actual steps to create a government that is free from deviant actions and of course members of DPRD throughout Indonesia must comply with these rules. The results of this study indicate that the behavior of DPRD members has an influence on the behavior of APBD corruption acts, where if the DPRD members comply with the applicable rules, they will be able to minimize fraudulent actions, namely corruption and vice versa. This is in line with the compliance theory proposed by Tyler in 1990. In the theory, it is explained that obedience is a discipline of individuals who obey the rules that have been previously set.

One that affects individual behavior is power, so individuals who have power have different behaviors than individuals who do not have power. Like DPRD members or parliamentarians they have different behaviors than other individuals because they are influenced by their power. The behavior of DPRD members regulated in article 90 of the attitudes and behavior of DPRD members as referred to in Article 89 paragraph (3) letter c number 1 contains several provisions. Disclosure is one of the causes of APBD corruption acts, but corruption in the APBD can be minimized by the existence of parliamentary behavior.

\section{Conclusion}

This study aims to determine the greedy effect, opportunity, need, and disclosure on the behavior of APBD corruption with parliament behavior as a moderating variable.

1. Based on the results of the analysis it shows that greed has a positive and significant impact on the behavior of APBD corruption acts. it means that the greater the greed of the individual, the higher the tendency for the behavior of corruption in the APBD.

2. Based on the results of the analysis show that opportunity has a positive and significant impact on the behavior of APBD corruption acts. This means that opportunity or opportunity is the cause of the acts of corruption in the APBD.

3. Based on the results of the analysis it indicates that need does not affect the behavior of APBD corruption actions. This means that the need or need is not the cause of the behavior of APBD corruption.

4. Based on the results of the analysis show that disclosure has a positive and significant effect on the behavior of APBD corruption actions. This means that the behavior of APBD corruption acts that occur is caused by disclosure or disclosure.

5. The results of the moderation regression analysis with the residual approach indicate that the interaction between parliamentary behavior and greedy influences the behavior of the APBD corruption act. This means that parliamentary behavior is a variable that weakens the greedy influence on the behavior of APBD corruption acts.

6. The results of the moderating regression analysis with the residual approach indicate that the interaction of parliamentary behavior and opportunity influences the behavior of the APBD corruption act. This means that parliamentary behavior is a variable that weakens the influence of opportunity on the behavior of APBD corruption acts.

7. The results of the moderating regression analysis with the residual approach indicate that the interaction between parliamentary behavior and need influences the behavior of the APBD 
corruption act. This means that parliamentary behavior is a variable that influences the influence of need on the behavior of APBD corruption acts.

8. The results of the moderating regression analysis with the residual approach show that the interaction between parliamentary behavior and disclosure influences the behavior of the APBD corruption act. This means that parliamentary behavior is a variable that weakens the effect of disclosure on the behavior of APBD corruption.

\section{References}

Apriani, Nidya., Edy Sujana., dan Gede Erni Sulindawati. 2017. Pengaruh Pressure, Opportunity, Dan Rationalization Terhadap Perilaku Kecurangan Akademik (Studi Empiris: Mahasiswa Akuntansi Program S1 Universitas Pendidikan Ganesha). e-journal. 7(01): 1-15

Azrianti , Ria Sari., Dwi Fitri Puspa dan Herawati. 2016. Analisis Faktor-Faktor Yang Mempengaruhi Korupsi Anggaran Pendapatan Belanja Daerah (Apbd) Di Sumatera Barat. 1-15.

Becker, J., Coonoly., Paula L., dan J. Morrison. 2006. Using The Bussines Fraud Triangle to Predict academic Dishonesty Among Busines Students. Academy of educational Leadership Journal. 10(1): 243-253.

Churchill, Ransford Quarmyne., William Agbodohu dan Peter Arhenful. 2013. Determining Factors Affecting Corruption: A Cross Country Analysis. International Journal of Economics, Business and Finance. 01(10): 275-285.

Dewayani, Rhety Ayu dan Anis Chairi. 2015. Money Laundering Dan Keterlibatan Wanita (Artis): Tantangan Baru Bagi Auditor Investigatif. Diponegoro Journal Of Accounting. 4(3): 23373806.

Elder, Randal J, Mark Beasley, Alvin A. Arens dan Amir Abadi Jusuf. 2008. Jasa Audit dan Assurance Pendekatan Terpadu (Adaptasi Indonesia). Penerbit Salemba Empat. Jakarta.

Gagola. 2008. Cheating In The Test: How to Do It, Detect It, and Prevent It. New jersey: lawrence erlbaum Associates Inc.

Ghozali, Imam. 2013. Aplikasi Analisis Multivariate Dengan Program SPSS. Edisi 3. Semarang: Badan Penerbit Universitas Diponegoro.

Halim, Abdul. 2003. Bunga Rampai Keuangan Daerah. UPP AMP YKPN. Jogjakarta.

Hasanah, Naimatul dan Nur Diana. 2018. Analsisi Pengaruh Fraud Diamond dan Gone Theory Terhadap Academic Fraud (Studi Kasus Terhadap Mahasiswa Program Studi Akuntansi Perguruan Tinggi Negeri dan Perguruan Tinggii di Malang. Jurnal Riset Akuntansi. 7(02): 113.

Helmuth, 2011. Better Performance With Performance Budgeting? Analyzing Cases of Succes And Failure In Public Administrations. International Public Mangement Jornal.

Indrawati, Gusti Ayu Putu., Purnamawati Gusti Ayu., dan Wikrama Ananta. 2017. Pengaruh Greed, Opportunity, Need, Disclosure Terhadap Perilaku Kecurangan Akademik Pada Mahasiswa Akuntansi Program S1 Negeri di Bali. E-Journal. 8 (2): 1-11.

Indriantoro, Nur., Bambang Supomo. 2014. Metodologi Penelitian Bisnis untuk Akuntansi dan Manajemen Edisi ketiga. BPFE Yogyakarta.

Ismetullah, Imset dan Elan Eriswanto. 2016. Analisis Pengaruh Teori Gone Fraud Terhadap Academic Fraud Di Universitas Muhammadiyah Sukabumi. Riset Akuntansi dan Keuangan Indonesia. 1(12): 134-142.

Istianah, Ida farida dan Krisdiyawati. 2016. Faktor-Faktor Yang Memotivasi Tindakan Korupsi Pada Anggaran Di Kab. Tegal. Journal. 7(01):1-16.

Jamaluddin.M, 2018. The Effect of Financial Distress and Disclosure on Going Concern Opinion of The banking Company Listing In Indonesian Stock Exchange. Internasional Journal of Scientific Research and Management, 6(1):64-70. 
Khaeruddin dan Rina Erlanda. 2016. Pengaruh Transparansi Dan Akuntabilitas Laporan Keuangan Pemerintah Daerah (Lkpd) Terhadap Tingkat Korupsi Pemerintah Daerah (Studi Pada Pemerintah Kota Se-Sumatera). Jurnal Akuntansi dan Keuangan. 7(02): 137-154.

Kompas. 2017. KPK kembali Tetapkan Setya Novanto Sebagai Tersangka E-KTP. http://nasional.kompas.com. Diakses pada tanggal 06/03/2018.

Kompas. 2017. Kasus Korupsi APBD, 2 Pimpinan DPRD Sulawesi Barat Ditahan. http://nasional.kompas.com. Diakses pada tanggal 06/03/2018

Kompas. 2018. Tiga Tersangka Kasus Suap APBD Jambi Akan Segera Disidang. http://nasional.kompas.com diakses pada tanggal 06/03/2018

Kuncoro Ph.D, Mudrajad. 2013. Metode Riset Untuk Bisnis dan Ekonomi Edisi 4. Jakarta: Erlangga. Kurniawan, Gusnardi. 2013. Pengaruh Moralitas, Motivasi dan Sistem Pengendalian Intern Terhadap Kecurangan Laporan Keuangan. Artikel Universitas Negeri Padang.

Lisa, Amelia Herman. 2013. Pengaruh Keadilan Organisasi Dan Sistem Pengendalian Intern Terhadap Kecurangan (Studi Empiris pada Kantor Cabang Utama Bank Pemerintah di Kota Padang). Artikel Universitas Negeri Padang.

Lonto dan Pangalila. 2013. Etika Kewarganegaraan. Yogyakarta: Penerbit Ombak.

Lopa, Baharuddin. 1997. Masalah Korupsi dan pemecahannya Cetakan I. PT Kipas Putih Akasa. Jakarta.

Mahmudi. 2011. Akuntansi Sektor Publik. Yogyakarta: UII Press.

Marliani, Mery dan Yulius Jogi, 2015. Persepsi Pengaruh Fraud Triangle Terhadap Pencurian Kas. Business Accounting Review. 3(2): 21-30.

Maulana, Zefri. 2016. Persepsi Masyarakat terhadap Faktor-faktor yang Mempengaruhi Korupsi Anggaran Pendapatan Belanja Daerah (APBD) di Aceh Utara. Jurnal Manajemen dan Keuangan. 5(02): 573-581.

Marlina, 201. Hukum Penitensier PT Refika Aditama. Bandung.

Muzadi, Hasyim. 2006. NU Melawan Korupsi "Kajian Tafsir dan Fiqh.” Cetakan I. Jakarta : Tim Kerja Gerakan Nasional Pemberantasan Korupsi.

Patricia, Nesa Lydia dan Sri Handayani. Pengaruh Gaya Hidup Hedonis Terhadap Perilaku Konsumtif Pada Pramugari Maskapai Penerbangan "X”. Jurnal Psikologi. 12(01): 10-17.

Peraturan Pemerintah Republik Indonesia No 16 Tahun 2010 Tentang Penyusunan Peraturan Dewan Perwakilan Rakyat Daerah.

Peraturan Pemerintah Republik Indonesia No. 31 Tahun 1999 Tentang Pemberantasan Tindak Pidana Korupsi.

Praditaningrum, Anugrah Suci. 2012. Analisis Faktor-Faktor yang Berpengaruh Terhadap Audit Judgment (Studi Pada BPK RI Perwakilan Provinsi Jawa Tengah). Jurnal Fakultas Ekonomi Universitas Diponegoro Semarang:1-45.

Rangkuti, Anna Armeini. 2011. Academis Cheating Behavior of Accounting Students: A Case Study in Jakarta State University. In Educational Integrity: Culture and Values. 105-109.

Rasyid, Ryaas. 1998. Desentralisasi Dalam Menunjang Pembangunan Daerah Dalam Pembangunan Administrasi di Indonesia. PT. Pustaka LP3ES. Jakarta.

Ratmono, Dwi, Y. Avrie d. A. Purwanto. 2014. Dapatkah Teori Fraud Triangle Menjelaskan Kecurangan dalam Laporan Keuangan?. SNA 17 Mataram 24-27 Sept 2014. Lombok Universitas Mataram.

Rusmita, Sari. 2015. Presepsi Mahasiswa Akuntansi Terhadap Korupsi. Jurnal Audit dan Akuntansi Fakultas Ekonimi dan Bisnis Universitas Tanjungpura. 4 (2): 1-22.

Sugiyono. 2013. Statistika Untuk Penelitian. Bandung: Alfabeta.

Suharsimi, Arikunto. 2000. Manajemen Penelitian. Jakarta: Rineka Cipta.

Scott, William R. 2000. Financial Accounting Theory. Second Edition.Canada : Prentice-Hall Canada Inc.

Syamsuddin, Aziz. 2013. Proses dan Teknik Penyusunan Undang-Undang. Jakarta: Sinar Grafika. 
Uwes Al-Qorni. 1999. 60 Penyakit Hati Cetakan 3. Bandung: Remaja Rosdakarya Offset. 1-51. Valensia. 2012. Presepsi Mahasiswa Akuntansi dan Non Akuntansi universitas Bina Nusantara Terhadap Korupsi. Jurnal universitas Bina Nusantara.

Wahyudi, Isa dan Sopanah. 2010. Analisis Faktor-Faktor Yang Mempengaruhi Korupsi Anggaran Pendapatan Belanja Daerah (APBD) Di Malang Raya. Jornal Universitas Muhammadiyah Gresik. 13(01): 1-53.

Widyastuti, Anastasia Reni. 2015. Disfungsionalisasi Birokrasi Sebagai Kendala Dalam Pemberantasan Korupsi. Journal Hukum. 4(03): 683-699.

Windarti. 2015. Pengaruh Fraud Triangle Terhadap Deteksi Kecurangan Laporan Keuangan Pada Perusahaan Manufaktur Yang Terdaftar Di Bursa Efekindonesia (Bei). Jurnal Manajemen dan Bisnis Sriwijaya. 13(02): 230-244.

Yeni. 2011. Presepsi Mahasiswa Akuntansi Universitas bina Nusantara Terhadap Fraudulent Financial Statement. Tesis Universitas bina Nusantara Jakarta.

Zaini. 2015. Analisis Pengaruh Fraud Diamond dan Gone Theory Terhadap Academic Fraud (Studi Kasus Mahasiswa Akuntansi Se-Madura). Simposium Nasional Akuntansi. 